\title{
UPAYA MENINGKATKAN KEMAMPUAN BERPIKIR KRITISMATA PELAJARAN BIOLOGI MELALUI PENDEKATAN (DISCOVERY LEARNING) PADA PESERTA DIDIK KELAS XII MIPA 2 SEMESTER GANJIL SMAN 1 BODEH TAHUN PELAJARAN 2019-2020
}

\author{
UMI NURKHANIFAH \\ SMA Negeri 1 Bodeh Pemalang \\ E-mail : khanifahsmanbo9@gmail.com
}

\begin{abstract}
ABSTRAK
Tujuan penelitian dengan menggunakan pendekatan pembelajaran Discovery Learning adalah siswa diharapkan mampu meningkatkan pemahaman terhadap materi Pembelahan sel. Penelitian ini dilakukan di SMA Negeri 1 Bodeh di kelas XII Mipa 2 Semester Gasal tahun ajaran 2019//2020subyek berjumlah 32 siswa, melalui penelitian tindakan kelas yang terdiri dari perencanaan, pelaksanaan tindakan, observasi dan refleksi dengan menggunakan model pembelajaran Discovery Learning. Tes digunakan untuk mengukur hasil belajar kemampuan awal siswa dan hasil belajar, dan lembar observasi digunakan untuk mengukur keterampilan berpikir kritis siswa.Pembelajaran dengan menggunakan model Discovery Learning terbukti efektif dalam meningkatkan hasil belajar siswa dan keterampilan berpikir kritis siswa.
\end{abstract}

Kata Kunci: Pemahaman, Discovery learning, Pembelahan sel

\section{PENDAHULUAN}

Kurikulum 2013 yang berlaku saat ini menuntut siswa untuk berperan aktif dalam proses belajar mengajar sehingga diperlukan strategi pembelajaran yang mendukung tercapai tujuan tersebut. Siswa sebagai subjek belajar harus berperan aktif dalam pembelajaran.Pada dasarnya pendidikan merupakan interaksi antara pendidik dengan siswa, untuk mencapai tujuan pendidikan yang berlangsung dalam lingkungan tertentu.Interaksi ini disebut interaksi pendidikan, yaitu saling pengaruh antara pendidik dengan siswa (Sukmadinata, 2012).Fungsi pendidikan adalah menyiapkan siswa.Menyiapkan diartikan bahwa siswa pada hakikatnya belum siap, tetapi perlu disiapkan dan sedang menyiapkan dirinya sendiri (Hamalik, 2013).

Dalam pembelajaran biologi diharapkan tidak hanya memberikan pengetahuan sebanyakbanyaknya kepada siswa, tetapi mampu merangsang berpikir, bersikap ilmiah dan kreatif serta tanggung jawab siswa terhadap peristiwa sehari-hari yang relevan dengan pelajaran biologi.melihat kenyataan ini diperlukan suatu solusi pembelajaran, dengan model pembelajaran yang sesuai diharapkan siswa akan lebih aktif,keaktifan belajar siswa menjadi penentu bagi keberhasilan pembelajaran yang dilaksanakan (Mulyasa, 2006).Menurut Purwanto (1997) tinggi rendahnya hasil belajar peserta didik dalam pembelajaran tidak terlepas daripemilihandan penggunaan metode pembelajaran.

Menurut Kurniasih, Imas \& Sani (2014) discovery learning didefinisikan sebagai proses pembelajaran yang terjadi bila materi pembelajaran tidak disajikan dalam bentuk finalnya, tetapi diharapkan siswa mengorganisasi sendiri. Salah satu ciri yang menunjukan keberhasilannya dilihat dari kadar kegiatan belajar siswa. Makin tinggi kegiatan belajar siswa, makin tinggi peluang berhasilnyapengajaran (Sudjana, 2012). Dipilihnya model pembelajaran Discovery Learning dengan pendekatan saintifik karena model ini memberikan kesempatan bagi siswa untuk berpikir, menemukan, berpendapat, dan saling bekerja sama melalui aktivitas belajar secara ilmiah, sehingga dapat melatih dan meningkatkan keterampilan berfikir kritis dan pemecahan masalah serta mendapatkan pengetahuan konsep-konsep penting yang nantinya akan berdampak pada peningkatan hasilbelajar.

Dalammengaplikasikanmetodediscovery learning peran guru terutama untuk menjamin 
agar kegiatan belajar menimbulkan rasa ingin tahu (kurioritas) siswa, meminimalkan risiko kegagalan belajar, dan agar belajar relevan dengan kebutuhan siswa (Suyono \& Hariyanto, 2012,hlm.88).Selain itu guru berperan sebagai pembimbing dengan memberikan kesempatan kepada siswauntukbelajarsecaraaktif,sebagaimana pendapat guru harus dapat membimbing dan mengarahkan kegiatan belajar siswa sesuai dengan tujuan (Sardiman, 2001).

Model pembelajaran Discovery Learning Menurut Kemendikbud (2013) memiliki dua langkah operasional yang harus dilaksanakan yaitu langkah persiapan dan pelaksanaan. Untuk itu peneliti ingin meningkatkan kemampuan berpikir kritis siswa melalui Penelitian Tindakan Kelas yang berjudul "Upaya Meningkatkan Kemampuan Berpikir KritisMata Pelajaran Biologi Melalui Pendekatan (DiscoveryLearning) Pada Peserta Didik Kelas XII Mipa 2 Semester Ganjil SMA N 1 Bodeh Tahun Pelajaran 2019-2020"

Berdasarkan latar belakang tersebut, maka rumusan masalah dalam penelitian tindakan kelas ini adalah; Bagaimana upaya meningkatkan kemampuan berpikir kritisserta persepsi siswa tentang materi pembelahan selmelalui model pembelajaran (discoverylearning) pada peserta didik kelas XII mipa 2 semester ganjil SMA N 1 Bodeh tahun pelajaran 2019-2020? Penelitian ini bertujuan untukmeningkatkan kemampuan berpikir kritisserta mengetahui persepsi siswa tentang materi pembelahan selmelalui pendekatan (discoverylearning) pada peserta didik kelas xii mipa 2 semester ganjil SMA N 1 Bodeh tahun pelajaran 2019-2020.

\section{METODE PENELITIAN}

Tempat penelitian ini dilaksanakan di kelas XII MIPA 2 SMA Negeri 1Bodeh terletak di Jalan Desa Babakan. Kegiatan penelitian ini dilaksanakan pada semester gasal tahun pelajaran 2019/2020 selama 2 bulan mulai dari minggu pertama bulan oktober sampai dengan minggu kedua bulan November yang meliputi penyusunan proposal sampai dengan penyusunan laporan Penelitian Tindakan Kelas. Penelitian tindakan kelas ini dilaksanakan secara kolaboratif partisipatif antara peneliti dengan guru Biologi SMA Negeri 1Bodeh sebagai pengamat. Subjek Penelitian tindakan kelas adalah peserta didik kelas XII MIPA2 SMA Negeri 1Bodehtahun pelajaran 2019/2020 dengan jumlah peserta didik sebanyak 32 orang terdiri dari 10 peserta didik putra dan 22 peserta didik putri. Sedangkan objek penelitian ini adalah peningkatan hasil belajar biologi dan keterampilan berpikir kritis peserta didik pada materi pembelahan sel.

Metode penelitian yang digunakan pada penelitian ini adalah metode Penelitian Tindakan Kelas (PTK) dengan dua siklus. Masing-masing siklus terdiri atas tahap-tahap perencanaan, tindakan, observasi dan refleksi. Penelitian ini dilakukan dengan tujuan untuk memperbaiki kualitas pembelajaran serta mengatasi berbagai permasalahan yang terdapat di dalam kelas seperti keterampilan berpikir kritis dan hasil belajar biologipeserta didik. Siklus PTK yang dilaksanakan dengan mengacu kepada teori Arikunto (2006 :16).Hasil yang diperoleh dari tahap observasi kemudian dikumpulkan dan dianalisa, dari hasil observasi apakah kegiatan yang dilakukan telah dapat meningkatkan hasil belajar biologi dan keterampilan berpikir kritis pada mata pelajaran biologi peserta didik di kelas XII MIPA 2 SMA N 1 Bodeh

\section{HASIL DAN PEMBAHASAN}

Data yang diperoleh dari hasil penelitian berupa angka-angka dianalisis untuk membuktikan hipotesis yang telah diajukan. Adapun analisis data hasil penelitian tersebut meliputi perolehan masing-masing peserta didik, rata-rata nilai kelas dan ketuntasan klasikal, disamping itu juga akan dibahas. Tes hasil belajar dilakukan pada awal dan akhir siklus 1 dan siklus 2 . Hasil tes ini digunakan untuk mengetahui tingkat pemahaman peserta didik terhadap materi pembelahan sel yang telah disampaikan oleh guru. Perolehan tes peserta didik pada masing-masing siklus dapat memperlihatkan peningkatan atau penurunan hasil belajar masing-masing peserta didik. Apabila digambarkan dalam tabel maka perolehan hasil belajar peserta didik mulai dari sebelum siklus 
sampai siklus 2 akan tampak sebagai berikut:

Pendidikan pada dasarnya merupakan interaksi antara pendidik dengan siswa, untuk mencapai tujuan pendidikan yang berlangsung dalam lingkungan tertentu.Interaksi ini disebut interaksi pendidikan, yaitu saling pengaruh antara pendidik dengan siswa (Sukmadinata, 2012).Fungsi pendidikan adalah menyiapkan siswa.Menyiapkan diartikan bahwa siswa pada hakikatnya belum siap, tetapi perlu disiapkan dan sedang menyiapkan dirinya sendiri (Hamalik, 2013).

Tabel 1. Perolehan nilai tes hasil belajar peserta didik kelas XII MIPA 2 Sebelum dan sesudah tindakan

\begin{tabular}{|c|c|c|c|c|c|}
\hline & \multirow[t]{2}{*}{ Nilai awal } & \multicolumn{2}{|c|}{ Nilai Siklus 1} & \multicolumn{2}{|c|}{ Nilai siklus 2} \\
\hline & & $\begin{array}{c}\text { Prete } \\
\text { st }\end{array}$ & $\begin{array}{c}\text { Poste } \\
\text { st }\end{array}$ & $\begin{array}{c}\text { Prete } \\
\text { st }\end{array}$ & $\begin{array}{c}\text { Poste } \\
\text { st }\end{array}$ \\
\hline Nilai & 83 & 87 & 95 & 92 & 97 \\
\hline $\begin{array}{c}\text { Tertinggi } \\
\text { Nilai } \\
\text { Terendah }\end{array}$ & 20 & 45 & 47 & 57 & 62 \\
\hline Rata-Rata & $\begin{array}{c}58,6 \\
9 \\
34,3 \\
8\end{array}$ & 56,25 & $\begin{array}{l}69,97 \\
71,88\end{array}$ & $\begin{array}{r}71,06 \\
78,13\end{array}$ & $\begin{array}{l}74,31 \\
84,38\end{array}$ \\
\hline $\begin{array}{c}\text { Ketuntasan } \\
(\%)\end{array}$ & $\begin{array}{l}11 \\
\quad \text { Pesert } \\
\text { a didik }\end{array}$ & $\begin{array}{l}18 \\
\text { Pesert } \\
\text { a didik }\end{array}$ & $\begin{array}{l}23 \\
\text { Pesert } \\
\text { a didik }\end{array}$ & $\begin{array}{l}25 \\
\text { Pesert } \\
\text { a didik }\end{array}$ & $\begin{array}{l}27 \\
\text { Pesert } \\
\text { a didik }\end{array}$ \\
\hline
\end{tabular}

Dari tabel diatas dapat disimpulkan bahwa terjadi peningkatan nilai rata-rata setiap siklus. Jadi model yang diterapkan ini memberikan dampak positif terhadap proses pembelajaran yang ditinjau dari peningkatan nilai rata-rata kelas yang meningkat setiap siklusnya.

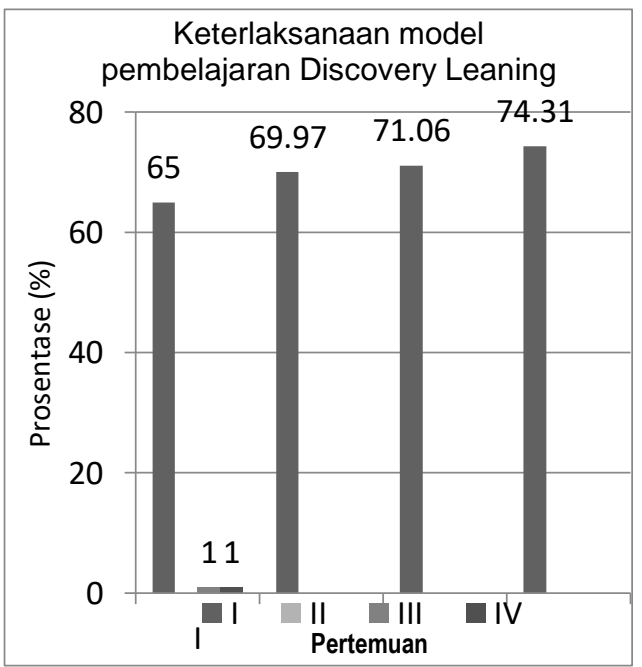

\section{Gambar 1. Peningkatan persentase hasil belajar sebelum dan sesudah menggunakan model Discovery Learning}

Berdasarkan hasil observasi diperoleh data bahwa keterampilan berpikir kritis dengan menggunakan model Discovery Learning mengalami peningkatan di setiap pertemuan dengan memperbaiki kekurangan yang terjadi di pertemuan sebelumnya. Adapun rincian mengenai 
peningkatan keterampilan berpikir kritis siswa dengan mengunakan model Discovery Learning dapat dilihat pada tabel dibawah

Tabel 2. Hasil Lembar Observasi Keterampilan Berpikir Kritis

\begin{tabular}{|c|c|c|c|c|c|}
\hline No & Indikator & $\begin{array}{c}\text { Persentase } \\
\text { Pertemuan } \\
1 \\
(\%)\end{array}$ & $\begin{array}{l}\text { Persentase } \\
\text { Pertemuan } \\
2(\%)\end{array}$ & $\begin{array}{l}\text { Persentase } \\
\text { Pertemuan } \\
3(\%)\end{array}$ & $\begin{array}{l}\text { Persentase } \\
\text { Pertemuan } \\
\quad 4(\%)\end{array}$ \\
\hline 1 & Melakukan & & & & \\
\hline & Pengamatan & 71 & 77 & 82 & 84 \\
\hline 2 & Merumuskan hipotesis & 71 & 79 & 83 & 83 \\
\hline 3 & Melakukan diskusi & 69 & 77 & 79 & 80 \\
\hline 4 & $\begin{array}{l}\text { Keterampilan peserta } \\
\text { didikbertanya }\end{array}$ & 74 & 80 & 85 & 85 \\
\hline 5 & $\begin{array}{l}\text { Keterampilan } \\
\quad \text { peserta } \\
\text { didik } \quad \text { menjawab }\end{array}$ & & & & \\
\hline & Pertanyaan & 66 & 78 & 83 & 84 \\
\hline 6 & Membuat Kesimpulan & 63 & 77 & 83 & 86 \\
\hline 7 & Menerapkan konsep & 74 & 78 & 81 & 83 \\
\hline
\end{tabular}

Dari tabel diatas dapat disimpulkan bahwa terjadi peningkatan nilai rata-rata setiap siklus. Jadi model yang diterapkan ini memberikan dampak positif terhadap proses pembelajaran yang ditinjau dari peningkatan nilai rata-rata kelas yang meningkat setiap siklusnya.

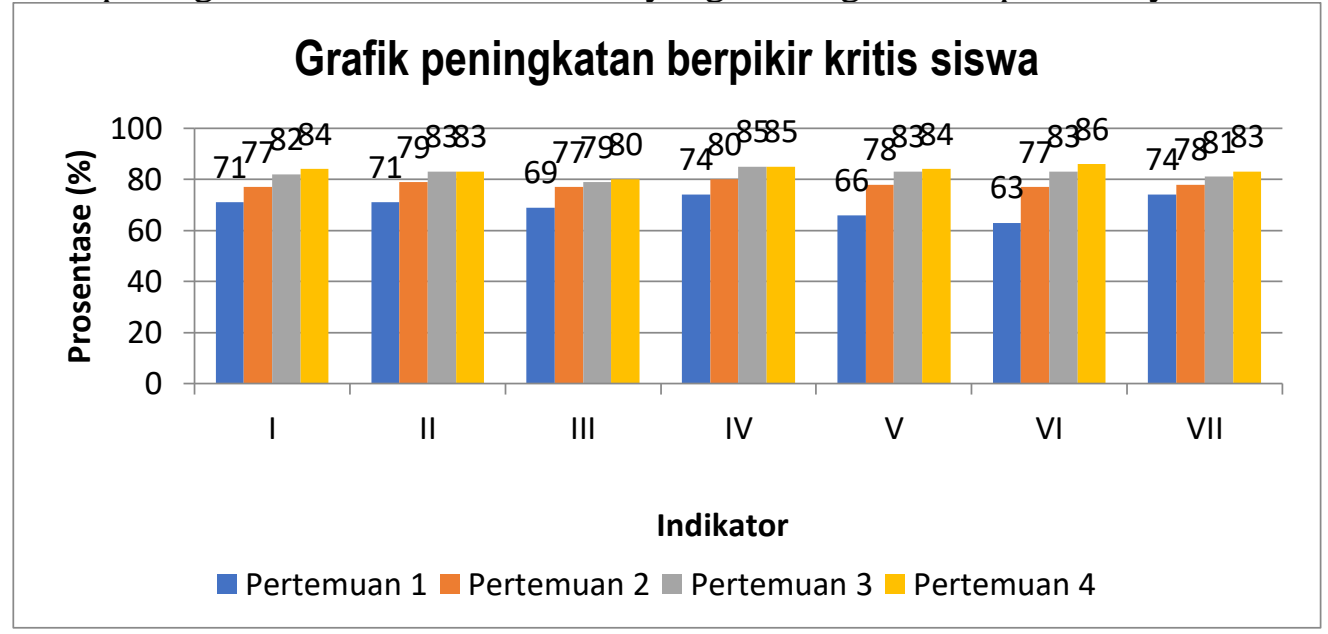

Gambar 2. Hubungan peningkatan hasil belajar dan keterampilan berpikir kritis siswa

\section{PEMBAHASAN}

Pembelajaran dengan menggunakan model Discovery Learning terbukti efektif dalam meningkatkan keterampilan berpikir kritis peserta didik. Dalam pembelajaran, aktivitas peserta didik selama mengikuti proses pembelajaran diperhatikan. Semakin peserta didik aktif, pembelajaran akan semakin efektif. Hal ini sesuai dengan pernyataan(Purwanto, 1997).strategi pembelajaran yang tepat akan membina peserta didik untuk berpikir mandiri dan menumbuhkan daya kreativitas, dan sekaligus adaptif terhadap berbagai situasi.Kenyataan menunjukan bahwa 
partisipasi peserta didik dalam pembelajaran meningkat ketika tahapan penemuan konsep digunakan.

Berdasarkan data hasil belajar siklus I diperoleh nilai rata-rata pretest I sebesar 65 nilai tertinggi yang diperoleh peserta didik sebesar 87, dan untuk nilai terendah sebesar 45 sedangkan hasil belajar postest I diperoleh nilai rata-rata postest I sebesar 69,97 nilai tertinggi yang diperoleh peserta didik sebesar 92 dan untuk nilai terendah sebesar 47, sedangkan siklus II diperoleh nilai rata-rata pretest II sebesar 71,06 nilai tertinggi yang diperoleh peserta didik sebesar 92, dan untuk nilai terendah sebesar 57 sedangkan hasil belajar postest II diperoleh nilai rata-rata postest II sebesar 74,31 nilai tertinggi yang diperoleh peserta didik sebesar 97 dan untuk nilai terendah sebesar 62.

Penerapan model pembelajaran Discovery Learning dapat meningkatkan keterampilan berpikir kritis siswa kelas XII MIPA 2 SMA Negeri 1 Bodeh Tahun Ajaran 2019/ 2020. Keberhasilan penerapan ditunjukan dengan adanya perubahan dalam proses siklus I persentase berpikir kritis siswa yang berada pada kriteria kritis dari 69,71\% naik menjadi $78 \%$ sedangkan pada siklus II persentase berpikir kritis siswa yang berada pada kriteria kritis dari 81,29\% naik menjadi pada kriteria sangat kritis $83,57 \%$. Berdasarkan hasil observasi diperoleh data bahwa keterampilan berpikir kritis dengan menggunakan model Discovery Learning mengalami peningkatan di setiap pertemuan dengan memperbaiki kekurangan yang terjadi di pertemuan sebelumnya.

Model Discovery Learning berpengaruh pada psikomotorik atau keterampilan peserta didik, dimana pada saat pembelajaran peserta didik dapat berpikir kritis dengan guru memberikan kesempatan kepada peserta didik untuk belajar secara aktif, guru juga memberikan kesempatan untuk menjawab dengan gagasan peserta didik sendiri dalam memecahkan masalah dengan mengembangkan kemampuan analisis dan mengolahinformasiyang didapat, peserta didik menjadi lebih terampil berbicara dalam mengemukakan pendapat. Kemudian peserta didik saling berkelompok untuk mendiskusikan hasil jawabannya bersama-sama sehingga aktivitas belajar peserta didik meningkat. Hal ini sesuai dengan pendapat Sukardjo dkk (2016), menyatakan bahwa model Discovery Learning dapat meningkatkan aktivitas belajar peserta didik dan ketrampilan berpikir terhadap hasil selajar.

Peningkatan aktivitas belajar peserta didik ini disebabkan oleh banyak faktor, antara lain model Discovery Learning yang menuntut peserta didik untuk lebih aktif dalam menemukan konsep \& materi, adanya kegiatan diskusi yang melatih peserta didik untuk aktif dalam proses pembelajaran. Dengan adanya diskusi, peserta didik lebih berani dalam menyatakan pendapat, menanggapi pernyataan baik teman maupun guru, dan bertanya mengenai hal -hal yang belum dipahami. Model Discovery Learning juga berpengaruh pada ranah afektif atau sikap peserta didik terutama pada tahap data collection. Peserta didik dituntut untuk mencatat semua data atau informasi yang diperoleh dari kegiatan pengamatan terhadap gambar guna menemukan konsep dan materi yang diharapkan, sehingga dari kegiatan ini akan terbentuk sikap jujur dan terbuka. Kemampuan berpikir kritis peserta didik juga telah dikembangkan melalui penerapan model Discovery Learning ini.

Salah satu strategi guru dalam mengembangkan keterampilan berpikir kritis dengan praktikum.Perkembangan ini juga nampak terlihat pada saat merancang percobaan yaitu ketika menentukan variabel percobaan, alat-alat dan bahan-bahan percobaan peserta didik sangat aktif bertanya dan antusias dalam mencari tahu jawabannya.metode praktikum peserta didik diberi kesempatan untuk mengalami sendiri atau melakukan sendiri, mengikuti suatu proses, mengamati suatu objek, menganalisis, membuktikan dan menarik kesimpulan sendiri suatu objek, keadaan atau proses tertentu. Dengan demikian peserta didik dituntut untuk mengalami sendiri, mencari kebenaran, atau mencari suatu hukum dan menarik kesimpulan atau proses yang dialaminya. Dengan pembelajaran praktikum ini keterampilan berpikir kritis peserta didik dapat ikut 
berkembang. Karena praktikum bukanlah sekedar untuk mempresentasikan apakah reaksinya cocok dengan teori tetapi juga harus mengembangkan proses berpikir dengan timbul pertanyaan mengapa reaksi demikian dan sebagainya.

Dari data diatas dapat disimpulkan bahwa terjadi peningkatan nilai rata-rata setiap siklus. Jadi model Discovery Learning yang diterapkan ini memberikan dampak positif terhadap proses pembelajaran yang ditinjau dari peningkatan nilai rata-rata kelas yang meningkat setiap siklusnya.

\section{KESIMPULAN}

Penerapan model pembelajaran Discovery Learning dapat meningkatkan hasil belajar kimia kelas XII MIPA 2 SMA Negeri 1Bodeh Tahun Ajaran 2019 /2020. Keberhasilan penerapan ditunjukan dengan adanya perubahan dalam proses siklus I kenaikan nilai rata-rata kelas setelah adanya tindakan dari semula pretest sebesar $56,25 \%$ naik menjadi $71,88 \%$ pada saat postest. Peningkatan jumlah peserta didik yang mencapai nilai KKM sebesar 15,63\%. Nilai yang dicapai masih dikategorikan dalam kriteria Baik dan sudah mencapai indikator keberhasilan yang peneliti tentukan. Saat pretest jumlah peserta didik yang tuntas sebanyak 18 siswa kemudian saat postest naik menjadi 23 siswa. Pada siklus II keberhasilan ditunjukan dengan kenaikan nilai rata-rata kelas setelah adanya tindakan dari semula pretest sebesar 78,13\% naik menjadi 84,38\% pada saat postest. Peningkatan jumlah peserta didik yang mencapai nilai KKM sebesar 6,25\%. Nilai yang dicapai masih dikategorikan dalam kriteria Sangat Baik dan sudah mencapai indikator keberhasilan yang peneliti tentukan. Saat pretest jumlah peserta didik yang tuntas sebanyak 25 siswa kemudian saat postest naik menjadi 27 siswa.

Penerapan model pembelajaran Discovery Learning dapat meningkatkan keterampilan berpikir kritis siswa kelas XII MIPA 2 SMA Negeri 1 Bodeh Tahun Ajaran 2019 / 2020. Keberhasilan penerapan ditunjukan dengan adanya perubahan dalam proses siklus I persentase berpikir kritis siswa yang berada pada kriteria kritis dari 69,71\% naik menjadi $78 \%$ sedangkan pada siklus II persentase berpikir kritis siswa yang berada pada kriteria kritis dari 82,28\% naik menjadi pada kriteria sangat kritis 83,57\%.

\section{DAFTAR PUSTAKA}

Arikunto, Suharsimi. 2006. Penelitian Tindakan Kelas. Jakarta.Bumi Aksara.

Hamalik, Oemar. 2013. Proses Belajar Mengajar.Jakarta.PT. Bumi Aksara.

Kemendikbud (2014).Materi Pelatihan Guru Implementasi Kurikulum 2013.

Kurniasih, Imas dan Sani, Berlin.(2014). Sukses Mengimplementasikan Kurikulum 2013. Surabaya: Kata Pena.

Mulyasa,E.(2006).MenjadiGuruProfesionalMenciptakanPembelajaranKreatifdanMenyenangkan. Bandung:Remaja Rosda Karya

Purwanto, M Ngalim. (1997). Psikologi Pendidikan.Bandung : PT. Remaja Karya.

Sardiman A.M. (2009). Interaksi dan Motivasi Belajar Mengajar.Jakarta : CV. Rajawali.

Sudjana, N. (2012). Penilaian Hasil Proses Belajar Mengajar. Bandung: PT. Remaja Rosdakarya

Sukardjo, M. dkk (2016).Pengaruh Strategi Pembelajaran dan Ketrampilan Berpikir Terhadap Hasil Belajar Piranti Sensor dan Aktivator.JPTV (Jurnal Pendidikan Teknik dan Vokasional) 2 (2). 1 - 10

Sukmadinata, Nana Syaodih. (2012). Kurikulum dan Pembelajaran Kompetisi. Bandung. Refika Aditama.

Suyono \& Hariyanto.(2012). Belajar dan Pembelajaran.Teori dan Konsep.Bandung : PT Remaja Rosdakarya 